The county analyst's pH studies confirmed the presence of variable high levels of alkalinity, and the numbers of cases were reduced when a neutralising agent was added to the final rinse.

The detergent did not contain enzymes but among its 14 constituents was a low concentration of an optical brightener (Blankophor MBBH 766). Optical brighteners have been known to cause contact dermatitis. ${ }^{1}$ The detergent also contained caustic soda and potassium hydroxide, both of which are more likely to be retained in cotton than in polyester sheets.

The rash seemed to be irritant rather than allergic. This was suggested by the short time interval between arrival on the site and development of the rash (some appeared within eight hours). An attack rate of over $75 \%$ in some school parties also suggested a cause to which a high percentage of people were susceptible. Unlike allergic contact dermatitis, irritant dermatitis may affect all those exposed to the irritant-people's thresholds, however, may differ.

The commercial nature of the centre, with large groups of people (over 9500 at times) arriving and departing at intervals of three days to a week made rechallenging those in whom the rash developed difficult to coordinate. Atopy is known to predispose to irritant contact dermatitis; the questionnaire did not, however, request details of past atopy or allergy because at the time of the investigation the priority was to find a common causal link between cases.

The epidemic was brought to the attention of the health authority by the unusual situation of the holiday centre, with up to 9500 people sharing a common environment and 7000 sleeping in sheets laundered at a common source. The problem itself was of little medical significance but attracted disproportionate media attention, without which it may not have come to immediate medical attention. There were many possible sources for irritant allergic rashes. No previous problems had been reported with the detergent, and there were no cases of the rash in places whose laundry was processed by the same source, but these factors were misleading.

In the margarine disease in Holland in 1960 a slapped face rash was also originally mistaken for a viral infection; in this case emulsifiers in margarine were eventually found to be the cause. ${ }^{2}$ Thus food and drink were included in the questionnaire survey. Other known causes of contact irritant dermatitis were covered. Airborne agents have been shown to provoke an irritant dermatitis ${ }^{3}$ and so the sprays and cleaning materials used to clean the showers were considered. The irritancy of soaps has been described at length ${ }^{+5}$ and among other factors the $\mathrm{pH}$ is a significant cause of irritation. Malten suggested that once integrity of the surface of the skin had been severed, many substances and influences with minor degrees of aggressiveness could penetrate the skin and thus may add to deranging its metabolism. ${ }^{6}$ Alkaloids affect the lipids at the skin surface and dissolve water holding substances; keratin cross linkages are broken, and water penetration causes swelling of the horny layer. ${ }^{7}$ Contact irritant dermatitis from use of detergents and cleaners in the workplace has been described by Mathias, who lists soaps, detergents, and other industrial cleaners as the second commonest cause of occupationally acquired dermatitis in California. ${ }^{8}$ Published reports tend to suggest that younger people (with the exception of neonates) are no more vulnerable to the effects of irritants than are adults. ${ }^{910}$ Our series of patients suggests that this is not the case, with $90 \%$ of those affected being under 14 years of age. Further analysis of those affected may help determine a relation between irritant dermatitis, atopy, and sex.

I thank staff at the holiday centre and the Environmental Health Department of West Somerset District Council for their help in the investigation; Drs C Bowie, A Bussey, A Hill and $\mathrm{A}$ Morkane for their advice throughout the investigations; Dr C J W Guerrier for dermatological advice; and Mrs $M$ Beavil for typing the script.

1 Osmundsen PE. Contact dermatitis due to an optical whitener in washing powders. Br $\mathcal{F}$ Dermatol 1969;81:799-803.

2 Doeglas HMG, Hermans E, Huisman J. The margarine disease. Arch Dermato 1965;83:175-81.

3 Dooms-Goossens AE, Debusschere KM, Gevers DM, Dupré KM, Degreef $\mathrm{HJ}$, Loncke JP. Contact dermatitis caused by airborne agents. 7 Am Acad Dermatol 1986;15:1-10.

Strube DD, Nicoll G. The irritancy of soaps and syndets. Cutis 1987:39:544-5.

Rycroft $R$, Wilkinson J. The principal irritants and sensitizers. In: Rook A, Wilkinson D, Ebling $F$, Champion $R$, Burton J, eds. Textbook of dermal $D$, Ebling $F$, Champion $R$, Burc 1986.533 .

Malen KE. Thoughts on irritant contact dermatitis. Conact Dermatits 1981:7:238-47.

Ryeci, R, Wilkinson J. Contact dermatis. In: Rook A, Wilkinson D,

Ebling F, Champion R, Burton J, eds. Textbook of Dermatology. 4th ed. Ebling F, Champion R, Burton J,

8 Mathias T. Contact dermatitis from use or misuse of soaps, detergents and cleaners in the workplace. Occupational Medicine 1986;1:205-18.

9 Kligmani AM. Cutaneous toxicology: an overview from the underside. Curren Problems in Dermatology 1978;7:1-25.

10 Harpin VA, Rutter N. Barrier properties of the newborn infant's skin F Paediatr 1983;102:419-25

(Accepted 11 November 1991$)$
Department of

Otolaryngology, University

Floor, Belfast City

Hospital, Belfast BT9 7AB

E J Stewart, FRCS, Allen and

Hanbury research registrar

$M$ J Cinnamond, FRCS,

professor of otolaryngology

Department of Respiratory Medicine, Royal Victoria

Hospital, Belfast BT12 6BA

R A Siddiqui, MRCP, senior house officer

D P Nicholls, MRCP,

consultant physician

C F Stanford, FRCP,

consultant physician

Correspondence to:

Dr C F Stanford, Wards

1 and 2, Royal Victoria

Hospital, Belfast BT12 6BA.

$B M \mathcal{F} 1992 ; 304: 479-80$

\section{Effect of a heat and moisture retaining mask on exercise induced asthma}

\section{E J Stewart, M J Cinnamond, R Siddiqui, D P Nicholls, C F Stanford}

Exercise induced asthma is less common during swimming than cycling or running, and the loss of heat and water is probably the stimulus to bronchoconstriction in susceptible subjects.' Avoiding rapid reheating after exercise also prevents this condition. An association between osmotic changes in bronchial epithelium and release of mediators from mast cells has been postulated. ${ }^{2}$ Currently, inhaled $\beta_{2}$ agonists or sodium cromoglycate administered before exercise are the preferred treatments, although good general control of asthma often reduces the incidence. We investigated whether using a mask that retains heat and moisture prevents the development of exercise induced asthma.

\section{Patients, methods, and results}

Four female and six male patients with asthma (age range 12-26) volunteered for the study. Their condition had been stable for several months, with symptoms being induced by exercise. No oral treatment was taken on the day of the exercise, and inhaled drugs were omitted for at least six hours. Patients were randomly allocated to exercise with or without a lightweight mask containing a filter that allowed exchange of heat and moisture (Filta Guard Mask, Intersurgical, Middlesex). The material of the filter is similar to that used in heat and moisture exchanges in intensive care. ${ }^{3}$ After 20 minutes of rest their forced expiratory volume in one second was measured. Exercise was performed on a cycle ergometer (three patients) or treadmill (seven) to achieve a pulse rate of $80 \%$ of maximum predicted values for age and sex. The forced expiratory volume in one second was measured immediately after exercise and then every four minutes for 20 minutes. The crossover arm of the study was performed on the same exercise machine during a second visit, which was at the same time of day and during the week after the first visit. The percentage 
reduction in the forced expiratory volume in one second after exercise was calculated using the preexercise value as the baseline value.

Statistical significance was calculated with Student's paired $t$ test. The study was approved by the research ethical committee of the Faculty of Medicine, Queen's University, Belfast.

The table shows the percentage reduction in forced expiratory volume in one second with and without using the mask. Only one patient (case 6) showed no improvement with the mask. The mean reduction in the group was $33 \cdot 7 \%$ (SE $3 \cdot 2 \%$ ) without the mask and $9 \cdot 1 \%(6 \cdot 1 \%)$ with it $(\mathrm{p}<0 \cdot 01)$. Most patients felt heat on their face but none complained of difficulty in breathing through the mask.

\section{Comment}

Our results show that a mask retaining heat and moisture effectively controlled exercise induced asthma in most of our asthmatic subjects. Previous work has shown that humidification of air can prevent the reduction in the forced expiratory volume. ${ }^{1}$ Storing exhaled air in a mask such as the one we used is a practical way to humidify and heat air, thus making both water and heat available for the next inspiration. The mask might be more beneficial in cold weather, which classically precipitates the development of exercise induced asthma. ${ }^{+}$The increased dead space from the mask does not play an important part during exercise.

We found that even with the mask the forced expiratory volume in one second decreased by $9 \cdot 1 \%$ after exercise. This reduction is, however, similar
Reduction in forced expiratory volume in one second $\left(F E V_{l}\right)$ after exercise with and without a mask in 10 asthmatic patients

\begin{tabular}{|c|c|c|c|c|c|c|}
\hline \multirow[b]{2}{*}{ Case No } & \multirow[b]{2}{*}{$\begin{array}{c}\text { Age } \\
\text { (years) }\end{array}$} & \multirow[b]{2}{*}{ Sex } & \multirow[b]{2}{*}{$\begin{array}{l}\text { Type of } \\
\text { exercise }\end{array}$} & \multirow{2}{*}{$\begin{array}{c}\text { Duration of } \\
\text { exercise }\end{array}$} & \multicolumn{2}{|c|}{ Reduction in $\mathrm{FEV}_{1}(\%)$} \\
\hline & & & & & $\begin{array}{l}\text { With } \\
\text { mask }\end{array}$ & $\begin{array}{l}\text { Without } \\
\text { mask }\end{array}$ \\
\hline 1 & 21 & $M$ & Treadmill & $12 \mathrm{~min}$ & 30 & 25 \\
\hline 2 & 18 & $\mathrm{~F}$ & Treadmill & $10 \mathrm{~min}$ & 31 & 8 \\
\hline 3 & 22 & $M$ & Treadmill & $13 \min 15 \mathrm{~s}$ & 52 & 9 \\
\hline 4 & 31 & $\mathrm{~F}$ & Treadmill & $9 \min 50 \mathrm{~s}$ & 39 & $0^{\star}$ \\
\hline 5 & 33 & $\mathrm{~F}$ & Treadmill & $7 \min 4 s$ & 23 & 9 \\
\hline 6 & 33 & $M$ & Cycle & $4 \min 12 s$ & 28 & 31 \\
\hline 7 & 12 & $\mathrm{~F}$ & Cycle & $3 \min 5 s$ & 31 & 14 \\
\hline 8 & 12 & $M$ & Cycle & $6 \mathrm{~min}$ & 43 & 36 \\
\hline 9 & 36 & $\mathrm{~F}$ & Treadmill & $6 \min 30 s$ & 18 & 0 \\
\hline 10 & 30 & $\mathrm{~F}$ & Treadmill & $8 \min 30 s$ & 42 & $0^{\star \star \star}$ \\
\hline
\end{tabular}

¿Improved $17 \%$.

$\star \star$ Improved $24 \%$

to that produced by sodium cromoglycate, ${ }^{5}$ which has been used for more than 20 years in treating exercise induced asthma. $\beta_{2}$ Agonists often completely abolish the drop in forced expiratory volume, but in some athletic contexts their stimulant effects may be disadvantageous. Masks may be helpful in the management of subjects who cannot or will not take prophylactic drug treatment.

1 Chen WY, Horton DJ. Heat and water loss from the airways and exerciseinduced asthma. Respiration 1977;34:305-13.

Anderson SD. Is there a unifying hypothesis for exercise induced asthma? f Allergy Clin Immunol 1984;73:660-5.

3 Evaluation report. Heat and moisture exchangers. $\mathcal{F}$ Med Eng Technol 1987;11: $117-27$

4 Strauss RH, McFadden ER, Ingram RH, Jaeger JJ. Enhancement of exercise induced asthma by cold air breathing. N Engl f Med 1977;297:743-7.

5 Chan-Yeung $M$. The effect of Sch 1000 and disodium chromoglycate on exercise induced asthma. Chest 1977;71:320-3.

(Accepted 1 October 1991 )
Department of

Therapeutics, University

Hospital, Nottingham

NG7 2UH

P D E Jones, PHD, research

fellow

$\mathrm{N}$ Hudson, $\mathrm{MB}$, research

fellow

C J Hawkey, DM, professor of gastroenterology

Correspondence to:

Professor Hawkey.

$B M \mathcal{F} 1992 ; 304: 480-1$

\section{Depression of salivary epidermal growth factor by smoking}

\author{
P D E Jones, N Hudson, C J Hawkey
}

Smoking is associated with the development of peptic ulceration, retarded ulcer healing, and enhanced ulcer relapse.' The mechanisms by which these associations arise are, however, unclear. Epidermal growth factor is a polypeptide secreted into saliva which stimulates epithelial proliferation, protects the mucosa against acute injury, and heals gastric and duodenal ulcers in both animals and humans. ${ }^{2}$ We have shown that output of salivary epidermal growth factor is diminished in patients with rheumatoid arthritis taking non-steroidal, anti-inflammatory drugs, ${ }^{3}$ a group prone to gastric ulceration. We investigated whether smoking might likewise be associated with reduced secretion of epidermal growth factor.

\section{Patients, methods, and results}

Patients attending for endoscopy over 26 months were interviewed and studied in the fasting state before endoscopy. Demographic information recorded included age, sex, smoking status (current smoker, exsmoker, never smoked), drug use, and history. On the basis of current or previous endoscopic findings patients were categorised as having gastric or duodenal ulceration, oesophageal ulceration or benign oesophageal stricture, or no upper gastrointestinal disease. Patients with other, miscellaneous, or mixed conditions were excluded from analysis, as were those taking nonsteroidal, anti-inflammatory drugs or drugs known to affect salivary flow.

Salivary flow was stimulated by the lingual appli- cation of citric acid. Saliva collected by aspiration with a dental sucker over 10 minutes was frozen and epidermal growth factor concentration measured using a radioreceptor assay. ${ }^{3}$ Results were logarithmically transformed to obtain a normal distribution and subjected to analysis of variance with comparison by $t$ test where significant differences were indicated.

\section{Results}

Satisfactory samples were obtained from 336 patients with normal findings on endoscopy (175) or ulceration (161). Overall the 222 current non-smokers (ex smokers and those who had never smoked) secreted a mean of $49.9 \mathrm{ng}$ of epidermal growth factor per 10 minutes ( $95 \%$ confidence interval 44.3 to $56 \cdot 2 \mathrm{ng} / 10 \mathrm{~min}$ ), and $95(43 \%)$ of them had ulcers. The 114 current smokers secreted $30.6(25 \cdot 1$ to $37 \cdot 3) \mathrm{ng}$ of growth factor $10 \mathrm{~min}$ $(\mathrm{p}<0.001)$ and a larger proportion of them $(64 ; 56 \%)$ had ulcers. Differences between current smokers and non-smokers remained significant when patients with duodenal ulceration and gastric ulceration were analysed separately (table)

To exclude the possibility that differences arose by confounding, patients who were current smokers were

Output of salivary epidermal growth factor in smoking and nonsmoking subgroups. Results are means (95\% confidence intervals)

\begin{tabular}{|c|c|c|c|c|c|}
\hline \multirow{2}{*}{$\begin{array}{l}\text { Endoscopic } \\
\text { findings }\end{array}$} & \multicolumn{2}{|c|}{ Non-smokers } & \multicolumn{2}{|r|}{ Smokers } & \multirow[b]{2}{*}{$\mathrm{p}$ Value } \\
\hline & No & $\mathrm{ng} / 10 \mathrm{~min}$ & No & $\mathrm{ng} / 10 \mathrm{~min}$ & \\
\hline Normal & 125 & $\begin{array}{c}53 \cdot 0 \\
(45 \cdot 2 \text { to } 62 \cdot 2)\end{array}$ & 50 & $\begin{array}{c}34 \cdot 8 \\
(29 \cdot 7 \text { to } 40 \cdot 9)\end{array}$ & $<0.001$ \\
\hline Duodenal ulcer & 50 & $\begin{array}{c}50.9 \\
(40.9 \text { to } 63.5)\end{array}$ & 36 & $\begin{array}{c}27 \cdot 1 \\
(17 \cdot 7 \text { to } 41 \cdot 5)\end{array}$ & 0.006 \\
\hline Gastric ulcer & 28 & $\begin{array}{c}54 \cdot 6 \\
(40 \cdot 1 \text { to } 74 \cdot 3)\end{array}$ & 22 & $\begin{array}{c}25 \cdot 5 \\
(14 \cdot 6 \text { to } 44 \cdot 8)\end{array}$ & 0.013 \\
\hline Oesophageal ulcer & 19 & $\begin{array}{c}45 \cdot 6 \\
(30 \cdot 3 \text { to } 68 \cdot 7)\end{array}$ & 6 & $\begin{array}{c}28 \cdot 2 \\
(16 \cdot 3 \text { to } 48 \cdot 7)\end{array}$ & NS \\
\hline
\end{tabular}

